\begin{tabular}{c} 
Volume and Issues Obtainable at Center for Sustainability Research and Consultancy \\
Journal of Business and Social Review in Emerging Economies \\
ISSN: 2519-089X \& ISSN (E): 2519-0326 \\
Volume 7: Issue 3 September 2021 \\
CSRᄃ \\
Journal homepage: www.publishing.globalcsrc.org/jbsee \\
\hline
\end{tabular}

\title{
The Impact of Female Directors on Board and Female CEO on Firm Performance: Empirical Evidence from Emerging Economy
}

\author{
*Muhammad Tasnim Khan, Dr. Hasan Murad School of Management, University of \\ Management Technology, Lahore, Pakistan \\ Sania Sarfraz, Department of Management Sciences, National University of Modern \\ Languages, Faisalabad Campus, Pakistan \\ Muhammad Husnain, Department of Business Administration, University of Sahiwal, Sahiwal, \\ Pakistan
}

*Corresponding author's email: tasnim.khan@umt.edu.pk

\begin{tabular}{l}
\hline ARTICLE \\
\hline History \\
Revised format: July 2021 \\
Available Online: Sept. 2021 \\
\hline Keywords \\
Board Structure, Gender \\
Diversity, Female CEOs, \\
Firm Performance, \\
Emerging Economy. \\
\hline
\end{tabular}

Jel Classification

M1, M2

\section{open ACCESS}

Purpose: As per agency theory prospective, board gender diversity enhances the corporate leadership structure which mitigates agency conflicts among stakeholders. Therefore, this study investigates the impact of female directors on board, and female CEOs on firm performance. We also uses board size, and board independence as board level control, while leverage, firm size, capital expenditure \& tangibility as firm level control.

Design/Methodology/Approach: The study uses a panel data starting from 2005 to 2020 on annual basis. To resolve endogeneity and unobserved heterogeneity problems in panel data analysis, study uses static (fixed effect, \& random effect) and dynamic (GMM) estimation techniques in Pakistan.

Findings: Result shows the positive impact of female directors on board and female CEOs on firm performance. These findings are robust under alternative measures of firm performance.

Implications/Originality/Value: The study suggests that female representation and female CEOs are the important attributes to enhance firm performance. Additionally, females are performing a significant role through monitor and control for excellent corporate leadership structure. Furthermore, this is the first study of its kind which analyzes this relationship in the emerging equity market of Pakistan.

(C) 2021, The authors, under a Creative Commons AttributionNonCommercial 4.0

Recommended citation: Khan, M. T., Sarfraz, S. and Husnain, M. (2021). The Impact of Female Directors on Board and Female CEO on Firm Performance: Empirical Evidence from Emerging Economy. Journal of Business and Social Review in Emerging Economies, 7 (3), 711 723. 


\section{Introduction}

The board of director performs specific functions such as appointing and remunerating of CEO (Campbell \& Mínguez-Vera, 2008), deducting effective and efficient strategies for companies interests (Abdullah \& Governance, 2014), monitoring and controlling the staff (Abdullah, 2004; O'connell \& Cramer, 2010), provide better information to managers and linking with external corporate governance environment (K1lıç \& Kuzey, 2016). These all functions make an entity of corporate governance to control all internal corporate governance responsibilities (Akbar, 2014). On the other hand, Abidin et al. (2009) documented corporate boards contributing for poor governance and declining the shareholder wealth. Researchers state different motives for poor corporate governance including, poor corporate leadership structure, ineffective monitoring, lack of check and balance by stakeholders (Kılıç \& Kuzey, 2016). These all issues create agency problems between shareholders and managers. Hence, Abdullah (2004) documented when staff and managers are disciplined and accountable through the board of directors, the firm entities and performance are enhanced accordingly.

Proponents of female directors suggest that higher gender diversity on board enhances the efficiency of the board by providing a breadth of resources such as symmetric information, legitimacy, experience, knowledge, external environment linkages, and source of dependency (Upadhyay \& Zeng, 2014). Furthermore, the penetration of women on board is seen to contribute a significant role to better corporate governance mechanisms by efficient monitoring and control of managers (Terjesen et al., 2016). However, the cultural and social reasons, the economic and financial arguments stirred the demand for high penetration of female directors on board worldwide. The presence of women on board as CEO capture 14\% percent in European developed countries (Marinova et al., 2016). The general example of a developed country like Norway, from the year of 2006 onwards, every organization must have as a minimum $40 \%$ of women participation in board. These practices are implemented in Belgium and Italy with a 33\% quota for female participation. Similarly, Spain and the Netherlands have $40 \%$, and $30 \%$ quota for the women in board, respectively. Therefore, women as CEO and high top position in corporate board create a significant impact on firm performance (Marinova et al., 2016).

As a stated relationship, the corporate environment in Pakistan provides a background to study the relationship among women on board and firm performance (Ullah et al., 2019). This environment is dominant for male board members rather than female representation in the corporate board. Mirza et al. (2012) investigated that it does not allow women to climb the ladder on the corporate board. Therefore, it is a debatable issue since there is no mandatory requirement in the corporate board for female representation in Pakistan still. Though, without mandatory obligation for females, they perform much more expertise in Pakistani firms. The descriptive statistics of CERB showed $42 \%$ of companies have one women director on the corporate board in Pakistan. Therefore, it offers a platform to investigate the impact of women directors on board on firm performance. Besides this, Pakistani firms are significantly influenced through political power and external corporate governance which create agency conflict between minority and shareholders (Yasser, 2012). Although, Ghazali and Bilal (2017) documented that Pakistani firms have much agency conflicts among all stakeholders. Consequently, it suggested that higher corporate governance mechanisms mitigate the agency problem for enhancing firm performance. Therefore, the presence of female directors may have a significant role by having gender diversity, which may enhance firm performance in emerging economies.

The objective of this study is to analyze the impact of female directors on board and female CEOs on firm performance based on PSX non-financial listed firms. The study uses a panel data 
sample starting from 2005 to 2020 annual basis. The board size, and board independence is using as governance level control variables, while leverage, firm size, capital expenditure, and tangible assets are using a firm's level control variables. To analyze the robust analysis, the study uses two alternative measures of firm performance i.e. return on asset, and return on equity. To resolve endogeneity and unobserved heterogeneity problems in panel data analysis, study uses GMM approach. The results of the fixed effect model, random effect model and the GMM approach shows that board gender diversity has an impact on the firm performance in emerging equity market of Pakistan. The benefits of female representation may be derived when female directors and female CEOs are hired with diverse knowledge, education, competencies, and life experience.

Next section discuss the theoretical background and hypothesis development of the study which is followed by the data and research methodology, the next section describes the empirical findings which is followed by the conclusion of the study.

\section{Theoretical Background and Hypothesis Development}

This section discusses the theoretical background and hypothesis development of the study.

\section{Agency Theory}

Corporate governance mechanism is a debatable issue in corporate world (Argyris, 1973; Jensen \& Meckling, 1976; Pound, 1988). It is investigated that corporate governance theories are relevant and perform a magnificent role in firm performance (Imade, 2019) which includes the agency theory, stakeholder theory, resource-dependent theory, political cost theory, transaction cost theory, and ethical based theories. Main focus of this study is on the agency theory. Agency theory assumes an economic model of a man and agent-principal relationship. Agent normally act in a self-interest way and increases his incentives (e.g. high salary etc.), and other economic gains (Imade, 2019). Though the model is individualistic, it depends upon the idea of an in-built conflict of self-interest among principal (owners) and agents (managers) of a company's resources (Donaldson \& Davis, 1991). The shareholders of the companies hire managers for their business and control all operations and govern the firm. When a manager's actions are diverted from the prime interests of shareholders, there comes the agency problem (Shleifer \& Vishny, 1997).

\section{Institutional Background}

The corporate leadership structure in Pakistan is different as compared to another developed economies. As a long time, the corporate culture in Pakistan has influenced by men dominating in which female performs duties as secondary rather than in primary management. Therefore, this culture has resembled male-dominated. Therefore, it creates a disparity between the culture when males and females reaching higher echelons of any firm. Notwithstanding, in the constitution of Pakistan 1973, the article of 38 "within the source of the country providing economic opportunities irrespective of sex, caste, creed or race, by raising their standard of living". On the other hand, the Government of Pakistan planning a document vision 2025 recognizing female's penetration in organizations, it creates a new chance to perform very well in a social-economical and corporate environment (Ullah et al., 2019). So, it is very important to give an overview of the association among female directors on board and females as CEO, and firm performance while, how female directors perform a significant role in corporate board. Carter et al., (2010) examine that many countries encourage and require firms to maintain the percentage of females perform duties as top management. Some develop European countries maintain the required quota for female directors (Marinova et al., 2016) and other countries provide quite a recommendation. Hence, higher presentation of female directors enhances 
corporate governance decision-making and monitoring ability (Adams \& Ferreira, 2009).

\section{Literature Review}

This section discusses the related literature and hypothesis development of the study.

\section{Gender diversity and Firm Performance}

In past studies, empirical results regarding the proportion of women directors on board and firm performance have been unpredictable, time-variant, contradictory, and inconclusive. The conflict in past research may be recognized to lack of control variables (Terjesen et al., 2016) unpredictable measurement of variables (Post et al., 2011) sample selection from different institutional (regulatory) contexts (Sabatier, 2015), and different time frames (Campbell \& Mínguez-Vera, 2008). Therefore, these studies examine the positive and significant relationship of female directors on firm performance (Abdullah, 2004; Mirza et al., 2012; Orazalin et al., 2020; Ullah et al., 2019). Whereas some studies investigate the negative association of gender diversity on firm performance (Adams \& Ferreira, 2009; Chapple \& Humphrey, 2014). While Rose (2007) claims there is no relationship exist between female representation and firm performance in Danish firms. Further, man recognizes only economic effect when making corporate decision whereas women recognize every aspect that effect of their decision (Hillman, 2015). Based on previous literature, researchers expect as compare to male, female have better corporate control and reduce agency problems Thus, researchers develop thy hypothesis:

H1: Women representation on board have a significant and positive impact on firm performance

\section{Female CEO and Firm Performance}

The past researchers documented that female CEO help to confine asymmetric information and agency conflicts (Chen et al., 2018). In addition, female CEOs perform great role in the implementation of a strong leadership structure and improve corporate investment decisions (Frye et al., 2018). Adams and Ferreira (2009) advise that female CEO play a significant role in a firm's monitoring intensity. Faccio et al. (2016) investigate after hiring the female CEOs, the firm significantly reduces its idiosyncratic risk. Khan et al. (2013) claim those firms having female CEOs, are better performance in terms of lower leverage, earning quality, and higher return on assets, higher tangibility, and lower capital expenditure than male CEOs firms. However, many studies doesn't investigate any difference between female and male fund managers (Atkinson et al., 2003). Johnson and Powell, (1994) documented that males and females have identical equality of decision making and same risk propensity. Based on previous literature, researchers expect as compare to male CEOs, female CEOs have better corporate control and reduce agency problems. Thus, researchers propose a hypothesis:

H2: Female CEOs have a positive and significant impact on firm performance

\section{Control Variables}

In the past researcher find contradictory results in support of board size and firm performance. Nonetheless, the advocate of agency theory suggests small board size is better than large board size (Khan et al., 2018). In the reference of Pakistan, Akbar (2014) claim a negative association between corporate board size and firm performance as a view of agency theory. While the literature on independent directors finds contradictory results with firm performance (Gutiérrez \& Sáez, 2013) and some other investigate no relationship between independent directors and firm performance (Hermalin \& Weisbach, 1991; Zahra \& Pearce, 1989). Prior researchers claim that leverage has a negative association with firm performance because the 
high level of the leverage ratio is closer to breaching debt covenants and exposing the firm to the risk of bankruptcy (Abdullah \& Governance, 2014). The risk of a high level of bankruptcy may be associated with a high level of debt ratio. According to Leland (1998), high leverage may motivate the managers to make risky divisions so they transfer wealth from shareholders to board holders. The firm size is considered an important factor of firm performance (Isidro \& Sobral, 2015). Large firm size has better performance as comparing the smaller size of firms and this can stem their higher market power (Lee, 2009). The capital expenditure used as a control variable in this study. Jiang et al. (2006) study in Taiwan and claim there is a positive and significant relationship between capital expenditure and corporate profits. The firm tangible assets are used as a factor of production, supply goods and services, and other administrative purposes (Chukwu \& Egbuhuzor, 2017). The tangible assets consist of property, plant, machinery, and equipment under the IAS international accounting standards, cover more than fifty percent of total assets and perform a significant role in firm performance. Therefore, we uses board size, and board independence as board level control, while leverage, firm size, capital expenditure \& tangibility as firm level control

\section{Research Methodology}

The objective of this study is to investigate the impact of female representation on board and female CEOs on firm performance. For this purpose, initially 200 non-financial firms are selected listed on PSX. Those firms selected for data analysis which have the highest market capitalization over fifteen years from 2005 to 2020 yearly basis. The study consists of panel and secondary data collected from firm's websites, annual report of firms, and PSX website. Some firms are excluded from the data based on; non-availability of corporate governance information like female directors, CEO and firm's director's profile, firms which are delisted, merged, and acquired at the end of 2020 also deleted from the sample. The overall sample size of 200 firms was taken at the start but due to the unavailability of data, and exclusion of firms, the final sample of 145 non-financial PSX listed firms is available for this study.

\section{Econometric Modeling}

The study uses different econometric techniques to validate the hypothesis. The descriptive statistics provide the summary of all data. The person's correlation of coefficient is a statistical technique it provides the association, strength, and direction of two quantitative variables. Through this technique, researchers also evaluate the multicollinearity problems of the data. The choice the most suitable technique among fixed effect, random effect is decided by the Hausman specification test (Hausman, 1978). The significant value of Hausman test rejects the null hypothesis thus, the random effect is constant and show fixed effect are most appropriate model (Saleh et al., 2021). To check the robustness of results, the study uses two different proxies (ROA and ROE) to measure the firm performance. Due to unobserved heterogeneity, endogeneity, and simultaneity biasness in panel data analysis, researchers apply the generalized method of moments (GMM) (Sarwar et al., 2019; Sarwar et al., 2018). The fixed effect and random effect are inconsistent methods because they could not properly address the endogeneity issues in panel data (Ullah et al., 2019). The issue of endogeneity occurs when independent variables are correlated with an error term and this problem mostly appears in panel data analysis (Adams \& Ferreira, 2009). Researchers investigate the GMM technique to provide effective results to analyze corporate governance variables by overcoming unobserved heterogeneity, autocorrelations, and endogeneity problems (Sarwar et al., 2018; Wintoki et al., 2012; MengYun et al., 2021). This assumption makes the GMM approach is superior as compare to other techniques like random effect, fixed-effect model, and OLS ordinary least square. Therefore, we also use GMM approach to identify and reduce possible unobserved heterogeneity, endogeneity, and simultaneity problems in panel data (Mubeen et al., 2020). We estimates the following 
equation in our study. Furthermore, all the variables proxies and abbreviations listed in Table 1.

We estimate the below equations to examine the impact of female directors on board on return on asset and return on equity.

$$
\begin{aligned}
R O A_{i t}=\beta_{0}+ & \beta_{1} F D_{i t}+\beta_{2} B S I Z E_{i t}+\beta_{3} B I N D_{i t}+\beta_{4} L E V_{i t}+\beta_{5} F S I Z E_{i t}+\beta_{6} C A P E_{i t} \\
& +\beta_{7} T N G_{i t}+\varepsilon_{i t} \ldots \ldots \ldots(1) \\
R O E_{i t}=\beta_{0}+ & \beta_{1} F D_{i t}+\beta_{2} B S I Z E_{i t}+\beta_{3} B I N D_{i t}+\beta_{4} L E V_{i t}+\beta_{5} F_{S I Z E_{i t}}+\beta_{6} C A P E_{i t} \\
& +\beta_{7} T N G_{i t}+\varepsilon_{i t} \ldots \ldots \ldots \text { (2) }
\end{aligned}
$$

We estimate the below equations to examine the impact of female CEO on return on asset and return on equity.

$$
\begin{aligned}
R O A_{i t}=\beta_{0}+ & \beta_{1} F M C_{i t}+\beta_{2} B_{S I Z E_{i t}}+\beta_{3} B I N D_{i t}+\beta_{4} L E V_{i t}+\beta_{5} F_{S I Z E_{i t}+\beta_{6} C A P E_{i t}} \\
& +\beta_{7} T N G_{i t}+\varepsilon_{i t} \ldots \ldots \ldots(3) \\
R O E_{i t}=\beta_{0}+ & \beta_{1} F M C_{i t}+\beta_{2} B S I Z E_{i t}+\beta_{3} B I N D_{i t}+\beta_{4} L E V_{i t}+\beta_{5} \text { FSIZE }_{i t}+\beta_{6} C A P E_{i t} \\
& +\beta_{7} T N G_{i t}+\varepsilon_{i t} \ldots \ldots \ldots(4)
\end{aligned}
$$

\begin{tabular}{|c|c|c|}
\hline Variables & Label & Measurement and Definitions \\
\hline \multicolumn{3}{|l|}{ Dependent Variables } \\
\hline Return on Assets & ROA & ROA = Net Income/Total Assets (Jaafar et al., 2019; Sarwar et al., 2020) \\
\hline Return on Equity & ROE & ROE $=$ Net Income/Total Shareholder Equity (Shafique et al., 2014) \\
\hline \multicolumn{3}{|l|}{ Independent Variables } \\
\hline Female Directors & FD & $\begin{array}{l}\text { FD = number of female directors on board/number of board members } \\
\text { (Ullah et al., 2019) }\end{array}$ \\
\hline Female CEO & FMC & $\begin{array}{l}\text { An indicating variable having value } 1 \text { if female as CEO, } 0 \text { otherwise (Frye } \\
\text { et al., 2018) }\end{array}$ \\
\hline \multicolumn{3}{|l|}{ Control Variables } \\
\hline Board Size & BSIZE & BSIZE $=$ Total number of board members (Wang et al., 2019) \\
\hline Board Independence & BIND & $\begin{array}{l}\text { BIND = Number of outside directors/number of board members (Chen et } \\
\text { al., 2018) }\end{array}$ \\
\hline Leverage & LEV & LEV = Long Term Debt / Total Assets (Khan et al., 2021) \\
\hline Firm Size & FSIZE & FSIZE $=$ Log (Total Assets) $($ Yasser et al., 2015) \\
\hline Capital Expenditure & CAPE & $\begin{array}{l}\text { CAPE = Total Capital Expenditure / Total Assets (Borghesi et al., 2016) } \\
\text { TNG = Total Tangible Assets / Total Assets (Chukwu \& Egbuhuzor, }\end{array}$ \\
\hline Tangibility & TNG & 2017) \\
\hline
\end{tabular}

Here, ROA denotes the return on asset, ROE shows the return on equity, FD shows the number of female director in board, FMC shows the female CEO, BSIZE shows the board size, BIND shows the board independence, LEV shows the leverage, FSIZE shows the firm size, CAPE shows the capital expenditure, and TNG shows the firm's tangibility.

Table 1 Measurement of the variables

\section{Empirical Findings}

This section discusses the empirical findings of the study.

\section{Descriptive Statistics}

Table 2 shows the descriptive summary of accounting-based performance measures with independent and control variables. The mean and standard deviation values of ROA (ROE) are $0.0394(0.0486)$ and $0.0785(0.0909)$ respectively. The maximum and minimum value of ROA is 0.1919 (-0.0506) and ROE 0.3220 (-0.0711) which are consistent with (Wang et al., 2019). About female directors, the obtain value of mean is 1.744 . The highest value of female directors is 6 and the lowest is 0 . It means female directors cover 1.744 percent of the total board size which indicates male board members are dominated in the corporate board. The value of standard deviation is 1.802 which indicates mediate variability in female directors between PSX listed firms. Studies find women on board perform duties as CEO with 0.403 percent of PSX 
listed firms. The results comprised of corporate governance control variables, the range of board size is 3 to 15 with a mean value of 7.99 and the standard deviation is 1.834 . It shows average board size consists of 8 members which is consistent with past study (Yasser, 2012). The average value of board independence is 1.485 , which means on average outside directors contain 1.48 percent of the total board size. Results comprised as firm's level control variables, the mean and standard deviation value of leverage, firm size, capital expenditure, and tangible assets are approximately $0.244(0.172), 6.732(0.613), 0.446(0.194)$, and $0.454(0.182)$ respectively. All results are aliens with previous studies (Shafique et al., 2014).

Table No 2. Descriptive Statistics

\begin{tabular}{lcccc}
\hline & Mean & Standard Deviation & Minimum & Maximum \\
\hline ROA & 0.0394 & 0.0486 & -0.0506 & 0.1919 \\
ROE & 0.0785 & 0.0909 & -0.0711 & 0.3220 \\
FD & 1.7446 & 1.8026 & 0.0000 & 6.0000 \\
FMC & 0.4034 & 0.5002 & 0.0000 & 1.0000 \\
BSIZE & 7.9997 & 1.8346 & 3.0000 & 15.000 \\
BIND & 1.4855 & 1.4812 & 0.0000 & 6.0000 \\
LEV & 0.2449 & 0.1720 & 0.0000 & 0.7561 \\
FSIZE & 6.7321 & 0.6135 & 5.2059 & 8.2391 \\
CAPE & 0.4467 & 0.1946 & 0.0583 & 0.8966 \\
TNG & 0.4546 & 0.1820 & -0.0011 & 0.8352 \\
\hline
\end{tabular}

\section{Correlation Matrix}

It's a statistical technique that shows the association between variables and displays the strength and direction of variables. The value of the Person coefficient is +1 to -1 respectively. Table 3 demonstrates the result of the Pearson coefficient correlation matrix for all dependent, independent, controls related to corporate governance and firm-level. Results show that there is no perfect correlation between all variables however, multicollinearity is not there in all regression models Table 3 results show the measures of firm performance are positive and significant relationship with female directors, female CEO, the board size, board independence, firm size, and tangible assets while ROA and ROE are negatively associated with leverage and capital expenditure.

Table No 3 Coefficient Correlation Matrix

\begin{tabular}{|c|c|c|c|c|c|c|c|c|c|c|}
\hline & ROA & ROE & FD & FMC & BSIZE & BIND & LEV & FSIZE & CAPE & TNG \\
\hline ROA & 1 & & & & & & & & & \\
\hline ROE & 0.710 & 1 & & & & & & & & \\
\hline FD & 0.076 & 0.060 & 1 & & & & & & & \\
\hline FMC & 0.101 & 0.101 & -0.297 & 1 & & & & & & \\
\hline BSIZE & 0.090 & 0.131 & 0.213 & -0.122 & 1 & & & & & \\
\hline BIND & 0.142 & 0.124 & 0.074 & 0.149 & -0.174 & 1 & & & & \\
\hline LEV & -0.329 & -0.149 & 0.063 & 0.131 & 0.039 & 0.091 & 1 & & & \\
\hline FSIZE & 0.270 & 0.312 & 0.066 & -0.094 & 0.167 & -0.123 & 0.112 & 1 & & \\
\hline CAPE & -0.240 & -0.235 & 0.031 & -0.007 & -0.092 & 0.038 & 0.122 & -0.119 & 1 & \\
\hline TNG & 0.312 & 0.064 & -0.036 & -0.079 & -0.029 & -0.080 & -0.629 & -0.052 & -0.128 & 1 \\
\hline
\end{tabular}




\section{Female Directors on Board and Firm Performance}

Table 4 demonstrates the result of the impact of female representation on ROA and ROE i.e. accounting-based measures of firm performance. The first three-column consists of random effects, fixed effect, and GMM for ROA while the other three are for ROE respectively. The coefficients of female directors FD of three techniques are positive 0.017, 0.002, 0.011 and significant with ROA besides coefficients of FD for ROE are 0.003, 0.002, 0.033 also positive and significant. However, it supports the H1. It means a higher percentage of female directors on board is beneficial to the improvement of the firm performance. These findings are consistent with Malik and Zahoor (2016), Yasser (2012), and Shafique et al. (2014) but have a contradiction with past studies (Kastlunger et al., 2010).

\section{Female CEO and Firm Performance}

Table 5 demonstrate the results of female CEO and firm performance. It includes three statistical techniques random effect, fixed effect, and GMM approach. The coefficient of female CEO for ROA is $0.009,0.019,0.005$ positive, and significant. While female CEO for ROE is 0.005, 0.007 , and 0.006 respectively. All coefficient is positive and significant of FMC to ROE. Therefore, $\mathrm{H} 2$ is acceptable. It indicates women on board as CEO will produce better results for firm performance while increasing productivity through the firm's assets and shareholder's equity (Benkraiem et al., 2017; Borghesi et al., 2016).

\section{Robust Analysis and Endogeneity Problems}

To check the robustness, researchers apply alternative measures and replace ROA with ROE which is another accounting-based measurement. The overall finding is similar to ROA. It means all results are robust through applying alternative proxies for the measurement of firm performance. To address the endogeneity problem and contour check the robustness of results, researchers apply the GMM approach. In earlier results, female directors and female CEO are positively associated with firm performance. Though, these results may suffer from endogeneity problems. Therefore, fixed effect and random effect may fail to address possible endogeneity problems of regressors but it's successful to identify the error term correlation issue. Therefore, the study re-estimates the model by using the generalized method of the moments GMM approach. 
Table. No 4. Female Directors on Board and Firm Performance

\begin{tabular}{|c|c|c|c|c|c|c|}
\hline \multirow[b]{2}{*}{ Variable } & \multicolumn{3}{|c|}{ ROA } & \multicolumn{3}{|c|}{$\mathrm{ROE}$} \\
\hline & Random Effect & Fixed Effect & GMM & Random Effect & Fixed Effect & GMM \\
\hline Lag & 0.291 & 0.025 & $0.045 *$ & 0.309 & 0.019 & $0.077 *$ \\
\hline FD & $0.017 *$ & $0.002 * * *$ & $0.011 * * *$ & $0.003 * *$ & $0.002 * *$ & $0.033 * * *$ \\
\hline BSIZE & $0.007 *$ & $0.023 *$ & $0.014 * * *$ & $0.002 * *$ & $0.005 *$ & $0.015 * * *$ \\
\hline BIND & $0.002 * *$ & $0.002 * *$ & $0.006^{* * *}$ & $0.004 * *$ & $0.004 * *$ & $0.007 * *$ \\
\hline LEV & $-0.079 *$ & $-0.093 * *$ & $-0.125^{* *}$ & $-0.123 *$ & $-0.161 * *$ & $-0.207 * *$ \\
\hline FSIZE & $0.013 * *$ & 0.010 & $0.048 * *$ & $0.027 * *$ & $0.008 * *$ & $0.029 * *$ \\
\hline CAPE & -0.041 & $-0.052 *$ & $-0.059 *$ & -0.078 & -0.064 & $-0.118 * *$ \\
\hline Constant & $-0.023 *$ & $0.142 *$ & -0.240 & $-0.020 * * *$ & $0.239 * * *$ & 0.204 \\
\hline Hausman Test & 0.0210 & & & 0.0001 & & \\
\hline Wald Stat & & 0.001 & & & 0.000 & \\
\hline Sargan Test & & & 0.124 & & & 0.182 \\
\hline $\mathrm{AR}(2)$ & & & 0.2310 & & & 0.1254 \\
\hline \multicolumn{7}{|c|}{$\begin{array}{l}\text { In this table, ROA denotes the return on asset, ROE shows the return on equity, FD shows the number of female director in board, FMC shows } \\
\text { the female CEO, BSIZE shows the board size, BIND shows the board independence, LEV shows the leverage, FSIZE shows the firm size, } \\
\text { CAPE shows the capital expenditure, and TNG shows the firm's tangibility. Furthermore, AR ( } 2 \text { ) shows the second order correlation. We } \\
\text { estimate the below equations to examine the impact of female directors on board on return on asset and return on equity. } * \text {, **, *** shows the } \\
\text { significance level at } 90 \%, 95 \% \text { and } 99 \% \text { respectively. }\end{array}$} \\
\hline
\end{tabular}


Table. No 5 Female CEO and Firm Performance

\begin{tabular}{|c|c|c|c|c|c|c|}
\hline \multirow[b]{2}{*}{ Variable } & \multicolumn{3}{|c|}{ ROA } & \multicolumn{3}{|c|}{ ROE } \\
\hline & Random Effect & Fixed Effect & GMM & Random Effect & Fixed Effect & GMM \\
\hline Lag & $0.295 * *$ & $0.026 * *$ & $0.037 * *$ & $0.311 * * *$ & $0.018 * * *$ & $0.052 * *$ \\
\hline FMC & $0.009 * *$ & $0.019 * * *$ & $0.005^{* * *} *$ & $0.005 * *$ & $0.007 * * *$ & $0.006 * * *$ \\
\hline BSIZE & $0.037 * *$ & $0.024 * * *$ & $0.004^{* * *} *$ & $0.001 * *$ & $0.006^{* *}$ & $0.014 * * *$ \\
\hline BIND & $0.002 * *$ & $0.002 * *$ & $0.008 * * *$ & $0.004 * *$ & $0.004 * *$ & $0.009 * *$ \\
\hline LEV & -0.080 & $-0.093^{*}$ & $-0.129 * *$ & $-0.125^{* *}$ & $-0.161^{* *}$ & $-0.234 * *$ \\
\hline FSIZE & $0.012 * *$ & $0.011 * *$ & $0.051 * *$ & 0.027 & $0.008 *$ & $0.037 * *$ \\
\hline CAPE & $-0.041 *$ & $-0.052 * *$ & $-0.078 * *$ & -0.080 & $-0.062 * *$ & $-0.157 * * *$ \\
\hline TNG & 0.022 & $0.024 * *$ & $0.135 * *$ & $0.078 * *$ & $0.094 * *$ & $0.014 * *$ \\
\hline Constant & -0.019 & 0.142 & $-0.289 *$ & $-0.009 *$ & 0.231 & $0.112 *$ \\
\hline Hausman Test & 0.0321 & & & 0.000 & & \\
\hline Wald Stat & & 0.000 & & & 0.023 & \\
\hline Sargan Test & & & 0.182 & & & 0.1920 \\
\hline AR (2) & & & 0.125 & & & 0.210 \\
\hline
\end{tabular}

In this table, ROA denotes the return on asset, ROE shows the return on equity, FD shows the number of female director in board, FMC shows the female CEO, BSIZE shows the board size, BIND shows the board independence, LEV shows the leverage, FSIZE shows the firm size, CAPE shows the capital expenditure, and TNG shows the firm's tangibility. Furthermore, AR (2) shows the second order correlation. We estimate the below equations to examine the impact of female CEO on board on return on asset and return on equity. *, **, *** shows the significance level at $90 \%, 95 \%$ and $99 \%$ respectively.

$$
\begin{aligned}
& R O A_{i t}=\beta_{0}+\beta_{1} F M C_{i t}+\beta_{2} B S I Z E_{i t}+\beta_{3} B I N D_{i t}+\beta_{4} L E V_{i t}+\beta_{5} F S I Z E_{i t}+\beta_{6} C A P E_{i t}+\beta_{7} T N G_{i t}+\varepsilon_{i t} \\
& R O E_{i t}=\beta_{0}+\beta_{1} F M C_{i t}+\beta_{2} \text { BSIZE }_{i t}+\beta_{3} B I N D_{i t}+\beta_{4} L E V_{i t}+\beta_{5} F S I Z E_{i t}+\beta_{6} C A P E_{i t}+\beta_{7} T N G_{i t}+\varepsilon_{i t}
\end{aligned}
$$




\section{Conclusion of study}

This study contributes to the literature regarding the impact of female directors on corporate boards and female CEOs on firm performance. For this purpose, we uses a sample of PSX 150 listed firms for the period of fifteen years from 2005 to 2020 on annual basis. To the best of the researcher's knowledge, this study is first to investigate the impact of gender diversity and female as CEO on firm performance with corporate board level and firm specific control for PSX listed firms.

The study finds evidence that female representation on corporate boards has a positive impact on firm performance. A study documented that a higher representation of female directors can enhance the firm performance by effective communication with potential clients (Rose, 2007). Besides, female CEOs also have a significant positive impact on firm performance. Female also improve the brand image (Lückerath-Rovers \& Governance, 2013), improve board effectiveness via bringing new ideas through diverse perspective (Carter et al., 2010). Finally, it also encourage middle-level management women through social and diversity beneficial information from top-level management (Dezsö \& Ross, 2012). There are several limitations of this study. Study restricted due to data limitations of corporate governance variables, and it also limited to Pakistan only. The study suggests some future recommendations for new researchers and practitioners. This study depends on panel secondary data analysis. It is possible other corporate governance control variables likewise CEO characteristics, board meetings, audit committee, board member tenure and internal control systems that are not investigate in this study might be influence the firm performance. Therefore, future researchers and practitioners investigate these aspects as well with firm performance.

\section{References}

Abdullah, S. N. (2004). Board composition, CEO duality and performance among Malaysian listed companies. Corporate Governance: The international journal of business in society.

Abdullah, S. N. (2014). The causes of gender diversity in Malaysian large firms. Journal of Management \& Governance, 18(4), 1137-1159.

Abidin, Z. Z., Kamal, N. M., \& Jusoff, K. (2009). Board structure and corporate performance in Malaysia. International journal of economics and finance, 1(1), 150-164.

Adams, R. B., \& Ferreira, D. (2009). Women in the boardroom and their impact on governance and performance. Journal of financial economics, 94(2), 291-309.

Atkinson, S. M., Baird, S. B., \& Frye, M. B. (2003). Do female mutual fund managers manage differently?. Journal of Financial Research, 26(1), 1-18.

Borghesi, R., Chang, K., \& Mehran, J. (2016). Simultaneous board and CEO diversity: does it increase firm value?. Applied Economics Letters, 23(1), 23-26

Carter, D. A., D'Souza, F., Simkins, B. J., \& Simpson, W. G. (2010). The gender and ethnic diversity of US boards and board committees and firm financial performance. Corporate Governance: An International Review, 18(5), 396-414.

Chapple, L., \& Humphrey, J. E. (2014). Does board gender diversity have a financial impact? Evidence using stock portfolio performance. Journal of business ethics, 122(4), 709723.

Chen, J., Leung, W. S., \& Evans, K. P. (2018). Female board representation, corporate innovation and firm performance. Journal of Empirical Finance, 48, 236-254. 
Dezsö, C. L., \& Ross, D. G. (2012). Does female representation in top management improve firm performance? A panel data investigation. Strategic management journal, 33(9), 1072-1089.

Donaldson, L., \& Davis, J. H. (1991). Stewardship theory or agency theory: CEO governance and shareholder returns. Australian Journal of management, 16(1), 49-64.

Faccio, M., Marchica, M. T., \& Mura, R. (2016). CEO gender, corporate risk-taking, and the efficiency of capital allocation. Journal of corporate finance, 39, 193-209.

Frye, M. B., \& Pham, D. T. (2018). CEO gender and corporate board structures. The Quarterly Review of Economics and Finance, 69, 110-124.

Ghazali, A., \& Bilal, A. R. (2017). Analyzing the link between agency problems, governance and control attributes for Pakistan. e-Finanse: Financial Internet Quarterly, 13(3), 4365.

Gutiérrez, M., \& Sáez, M. (2013). Deconstructing independent directors. Journal of Corporate Law Studies, 13(1), 63-94.

Hausman, J. A. (1978). Specification tests in econometrics. Econometrica: Journal of the econometric society, 1251-1271.

Hillman, A. J. (2015). Board diversity: Beginning to unpeel the onion. Corporate Governance: An International Review, 23(2), 104-107.

Isidro, H., \& Sobral, M. (2015). The effects of women on corporate boards on firm value, financial performance, and ethical and social compliance. Journal of Business Ethics, 132(1), 1-19.

Jaafar, A., Hodgkinson, L., \& Kao, M. F. (2019). Ownership Structure, Board of Directors and Firm Performance: Evidence from Taiwan (No. 19011).

Jensen, M. C., \& Meckling, W. H. (1976). Theory of the firm: Managerial behavior, agency costs and ownership structure. Journal of financial economics, 3(4), 305-360.

Jiang, C. H., Chen, H. L., \& Huang, Y. S. (2006). Capital expenditures and corporate earnings: Evidence from the Taiwan Stock Exchange. Managerial Finance.

Johnson, J. E., \& Powell, P. L. (1994). Decision making, risk and gender: Are managers different?. British journal of management, 5(2), 123-138.

Khan, M. T., Anwar, M. M., \& Husnain, M. (2021). The Relationship Between Corporate Diversification and Tax Avoidance: Empirical Evidence from the Emerging Economy of Pakistan. Journal of Accounting and Finance in Emerging Economies, 7(1), 35-52.

Khan, W. A., \& Vieito, J. P. (2013). CEO gender and firm performance. Journal of Economics and Business, 67, 55-66.

Kilıç, M., \& Kuzey, C. (2016). The effect of board gender diversity on firm performance: evidence from Turkey. Gender in management: An international journal.

Lee, J. (2009). Does size matter in firm performance? Evidence from US public firms. international Journal of the economics of Business, 16(2), 189-203.

Leland, H. E. (1998). Agency costs, risk management, and capital structure. The Journal of Finance, 53(4), 1213-1243.

Lückerath-Rovers, M. (2013). Women on boards and firm performance. Journal of Management \& Governance, 17(2), 491-509.

Malik, M. S., \& Zahoor, N. (2016). Do females in top management affect firm performance? Evidence from Pakistan. Pakistan Journal of Gender Studies, 12(1), 101-112.

Marinova, J., Plantenga, J., \& Remery, C. (2016). Gender diversity and firm performance: Evidence from Dutch and Danish boardrooms. The International Journal of Human 
Resource Management, 27(15), 1777-1790.

Mengyun, W., Um-E-Habiba, Akbar, D., Basit Memon, M. A., \& Husnain, M. (2021). Analyzing the Role of Board Independence towards Corporate Cash Holding: Evidence from Listed Family Firms of Emerging Economy. Journal of Contemporary Issues in Business and Government, 27(3), 1360-1369.

MengYun, W., Um-E-Habiba, Husnain, M., Sarwar, B., \& Ali, W. (2021). Board Financial Expertise and Corporate Cash Holdings: Moderating Role of Multiple Large Shareholders in Emerging Family Firms. Complexity, 2021.

O'connell, V., \& Cramer, N. (2010). The relationship between firm performance and board characteristics in Ireland. European management journal, 28(5), 387-399.

Post, C., Rahman, N., \& Rubow, E. (2011). Green governance: Boards of directors' composition and environmental corporate social responsibility. Business \& society, 50(1), 189-223.

Pound, J. (1988). Proxy contests and the efficiency of shareholder oversight. Journal of financial economics, 20, 237-265.

Rose, C. (2007). Does female board representation influence firm performance? The Danish evidence. Corporate Governance: An International Review, 15(2), 404-413.

Sabatier, M. (2015). A women's boom in the boardroom: effects on performance?. Applied Economics, 47(26), 2717-2727.

Sarwar, B., Kutan, A., Ming, X. and Husnain, M. (2020), "How do talented managers view dividend policy? Further evidence from Chinese equity market", International Journal of Emerging Markets, Vol. 15 No. 3, pp. 559-586.

Sarwar, B., Ming, X., \& Husnain, M. (2020). Economic policy uncertainty and dividend sustainability: new insight from emerging equity market of China. Economic researchEkonomska istraživanja, 33(1), 204-223.

Sarwar, B., Xiao, M., Husnain, M. and Naheed, R. (2018), "Board financial expertise and dividend-paying behavior of firms: New insights from the emerging equity markets of China and Pakistan", Management Decision, Vol. 56 No. 9, pp. 1839-1868.

Shafique, Y., Idress, S., \& Yousaf, H. (2014). Impact of boards gender diversity on firms profitability: Evidence from banking sector of Pakistan. European Journal of Business and Management, 6(7), 296-307.

Shleifer, A., \& Vishny, R. W. (1997). A Survey of Corporate Governance, 52 J. Fin, 737(738), 740-748.

Terjesen, S., Couto, E. B., \& Francisco, P. M. (2016). Does the presence of independent and female directors impact firm performance? A multi-country study of board diversity. Journal of Management \& Governance, 20(3), 447-483.

Upadhyay, A., \& Zeng, H. (2014). Gender and ethnic diversity on boards and corporate information environment. Journal of Business Research, 67(11), 2456-2463.

Wintoki, M. B., Linck, J. S., \& Netter, J. M. (2012). Endogeneity and the dynamics of internal corporate governance. Journal of financial economics, 105(3), 581-606.

Yasser, Q. R., Al Mamun, A., \& Suriya, A. R. (2015). CEO duality structure and firm performance in Pakistan. Asian Journal of Accounting and Governance, 5, 57-69.

Yasser, Q. R. (2012). Affects of female directors on firms performance in Pakistan. Modern Economy, 3, 817-825.

Zahra, S. A., \& Pearce, J. A. (1989). Boards of directors and corporate financial performance: A review and integrative model. Journal of management, 15(2), 291-334. 